\title{
Management of Gestational Diabetes Mellitus in A Beta Major Thalassemia Patient
}

\author{
Troy Fonda ${ }^{1}$ (D) Hermina Novida ${ }^{2 *(\mathbb{D})}$ \\ ${ }^{1}$ Faculty of Medicine, Universitas Airlangga - Dr. Soetomo General Academic Hospital, Surabaya, Indonesia \\ ${ }^{2}$ Department of Internal Medicine, Faculty of Medicine - Dr. Soetomo General Academic Hospital, Surabaya, Indonesia
}

\begin{abstract}
A B S T RA C T
Gestational diabetes mellitus (GDM) is a hyperglycemic condition that is first discovered during pregnancy. GDM is a high-risk condition during pregnancy, for both mother and fetus. GDM affects about 1-14\% of pregnancies. In the last 20 years, the incidence of gestational diabetes has been increasing. High iron load and disorders of iron metabolism have been associated with glucose metabolism. The beta thalassemias are a group of hereditary hemoglobinopathies. Treatment for beta thalassemias patients is transfusion, but intensive transfusion can aggravate iron overload in patients. In this study, a case of GDM in a pregnant woman with beta-thalassemia was reported.
\end{abstract}

Keywords: Gestational diabetes mellitus, Management, Thalassemia

Correspondence: Hermina Novida

E-mail: hermina-n@fk.unair.ac.id

Article history: • Received 26 Novembre $2020 \bullet$ Received in revised form 11 January $2021 \bullet$ Accepted 8 February 2021

\section{INTRODUCTION}

Gestational diabetes mellitus (GDM) is a hyperglycemic condition that is first discovered during pregnancy. GDM is a high-risk condition during pregnancy, for both mother and fetus. The risk of miscarriage, pre-eclampsia, and preterm labor are higher in women with diabetes (Zhang et al., 2018; NICE, 2019).

GDM affects about $1-14 \%$ of pregnancies. In the last 20 years, the incidence of gestational diabetes has been increasing. There are a lot of risk factors for GDM, such as high body mass index (BMI), older age, family history of diabetes, and disorders of iron metabolism. High iron load and disorders of iron metabolism have been associated with glucose metabolism (Helin et al., 2012; Zhang et al., 2018).

The beta thalassemias are a group of hereditary hemoglobinopathies. Treatment for beta thalassemias patients is transfusion, but intensive transfusion can aggravate iron overload in patients. Pregnancy causes metabolic changes that promote adipose tissue in early gestation and insulin resistance in late pregnancy. It causes GDM can be easier occurred (Petrakos et al., 2016; Zhang et al., 2018).

Studies of total iron intake and the risk of GDM are rare. Some studies have reported the correlation of iron intake only from food or drug and diabetes so they failed to report the effect of total iron intake (Helin et al., 2012). In this study, a case of GDM in a pregnant woman with beta-thalassemia was reported.

\section{CASE REPORT}

Lady ER, age 28 y.o. from Surabaya. She was consulted by obgyn colleagues with a request for gestational diabetes screening. The patient was pregnant with gestational age 27/28 weeks with the first day of menstruation at last April 24th, 2017. She did not feel any complaints. There are no increase of appetite, excessive thirst and hunger, frequent urination, nor weight loss. She was diagnosed betathalassemia major since the age of 11 y.o and received Packed Cell Leucoreduction transfusions every 2 months with consumption of deferasirox. Patients also had a history of splenectomy in 2004. During pregnancy, haematology and oncology division planned to give her transfusion of Packed Cell Leucoreduction every month to maintain $\mathrm{Hb}$ above 10 $\mathrm{g} / \mathrm{dl}$. There was no personal history of diabetes, hypertension and other diseases, also no history of contraception before. There weren't other family members suffering from diabetes.

On physical examination, she was alert with Glasgow Coma Scale (GCS) E4V5M6. Blood pressure (BP) was $100 / 60 \mathrm{mmHg}$, pulse 84 beats/minute, regular, respiratory rate (RR) 20 times/minute and axillary temperature $36.8 \mathrm{C}$. The patient was $150 \mathrm{~cm}$ in height with a body weight $51 \mathrm{~kg}$ (BMI: $22.67 \mathrm{~kg} / \mathrm{m}^{2}$ ), her body weight before pregnant was 37 kg (BMI: $16.45 \mathrm{~kg} / \mathrm{m}^{2}$ ). Head and neck examination showed conjungtival pallor. There was no abnormality detected in lung and heart examination. From abdominal examination, fundal uterine height $24 \mathrm{~cm}$, head position, fetal heart rate 12-12-13 (normal), no uterine contraction detected. 
Extremities perfusion were warm and dry, no edema and cappilary refill time $<2$ seconds. From laboratory examination, Hemoglobin $8.8 \mathrm{~g} / \mathrm{dl}$, hematocrit 28.1\%, leukocytes $12750 / \mu \mathrm{L}$, neutrofil $60.3 \%$, platelets $771000 / \mu \mathrm{L}$, 1-hour 50-gram glucose load test $144 \mathrm{mg} / \mathrm{dl}$, ferritin $12696.12 \mathrm{mcg} / \mathrm{l}$.

Based on examination, the patient'sinitial assesment was Gravida 1 P0000 27-28 week intrauterine with major beta thalassemia and suspect gestational diabetes mellitus. The patient was given $3 \times 1 \mathrm{mg}$ of folic acid, calsium 2x500 mg, and transfusion of Packed Cell Leucoreduction every month to maintain $\mathrm{Hb}$ above $10 \mathrm{~g} / \mathrm{dl}$. Complete blood tests are planned every month. An oral glucose tolerance test 3 hours with 100 gram glucose as well as HOMA IR and HOMA $\beta$ examination are planned.

\section{Clinical Progression}

On 1 week after, the patient had no complaints. From laboratory tests, $\mathrm{Hb} 8.4 \mathrm{~g} / \mathrm{dl}$, hematocrit $27.8 \%$, leukocytes $16380 / \mu \mathrm{L}$, platelets $757000 / \mu \mathrm{L}$. An oral glucose tolerance test was performed with 100 gram glucose load and obtained fasting blood sugar results $99 \mathrm{mg} / \mathrm{dl}, 1$ hour $224 \mathrm{mg} / \mathrm{dl}, 2$ hours $183 \mathrm{mg} / \mathrm{dl}$ and 3 hours $116 \mathrm{mg} / \mathrm{dl}$, fasting insulin 18.8 uIU/ml, HOMA IR 4.6, HOMA $\beta$ 67\%. Patient was diagnosed with Gravida 1 P0000 28-29 weeks, single intrauterine with beta major thalassemia and gestational diabetes mellitus. We treated the patient with lifestyle modification (diet B1 T3 1800 calories/day) and other therapies were continued. We planned to performed complete blood count (CBC) test, fasting glucose and 2 hour post prandial test 1 week after lifestyle and diet modification.

On 1 week after diet management, the patient came again with laboratory tests showed fasting blood sugar $89 \mathrm{mg} / \mathrm{dl}$, blood sugar 2 hours after meals $108 \mathrm{mg} / \mathrm{dl}$. Patient was diagnosed with Gravida 1 P000 29-30 weeks, intrauterine with beta major thalassemia and controlled gestational diabetes mellitus. Therapies were continued and patient was planned to take complete blood tests, fasting glucose and 2 hour post prandial monthly.

The patient came every month for check up. Her condition was within normal limit. Her fasting blood glucose, 2 hours post prandial and other laboratory tests were within normal limit. Therapies were continued.

The patient gave birth a baby girl at $37 / 38$ weeks of gestation with a birth weight $2400 \mathrm{gr}$, a length $48 \mathrm{~cm}$ by caesarean sectio for indications of the secondary arrest of dilation. One week after giving birth, patient had no complaints. Laboratory examination showed $\mathrm{Hb} 9.8 \mathrm{~g} / \mathrm{dl}$, hematrocrit $31.7 \%$, leukocytes $14170 / \mu \mathrm{L}$, platelets 770000 / $\mu \mathrm{L}$, fasting blood sugar $79 \mathrm{mg} / \mathrm{dl}$, blood sugar two hours post prandial 95 mg/dl. Planning: diet B1 1500 calories with oral chelating agent, OGTT 1 month after.
The patient returned two months after giving birth. Patient had no complaints. The patient was $150 \mathrm{~cm}$ in height with a body weight $50 \mathrm{~kg}$ (BMI: $22.22 \mathrm{~kg} / \mathrm{m}^{2}$ ). From laboratory tests $\mathrm{Hb} 7.7 \mathrm{~g} / \mathrm{dl}$, hematrocrit 24.8\%, leukocytes $13320 / \mu \mathrm{L}$, platelets $715000 / \mu \mathrm{L}$, fasting blood sugar $87 \mathrm{mg} / \mathrm{dl}$, blood sugar one hour post 75 gram glucose load $155 \mathrm{mg} / \mathrm{dl}$, two hours $131 \mathrm{mg} / \mathrm{dl}$. Planning diet B1 1500 calorieswith oral chelating agent and control monthly for monitoring.

\section{DISCUSSION}

Hyperglycemia during pregnancy can be caused by diabetes (patient with history of diabetes) or gestational diabetes mellitus. Gestational diabetes mellitus (GDM) is a hyperglycemic condition that's first discovered during pregnancy. GDM is a high-risk condition for both mother and fetus (Adam et al., 2014; NICE, 2019).

Women in South East Asians countries have high prevalence of type II diabetes mellitus and genetic predisposition so universal screening for GDM is needed. Screening for GDM shoud be performed at 24-28 weeks of gestation because insulin resistance increases during the second trimester and glucose levels rise in women who had glucose metabolism disturbances. One of condition related with an increased risk of disturbances in glucose metabolism is high iron load and disorders of iron metabolism. The patient had been diagnosed with beta thalassemia and had been on routine blood transfusion with ferritin 12696.12 $\mathrm{mcg} / \mathrm{l}$. She was also from South East Asian countries (Indonesia), so she needed to be screened for GDM (Helin et al., 2012; Rani et al., 2016; ADA, 2018; Zhang et al., 2018).

There are two criteria diagnosis of GDM, from World Health Organization (WHO) and American Diabetes Association (ADA). From American Diabetes Association 2018, there are two strategies one-step and two-step strategy. We used two-step strategy from ADA. The protocol for two step strategies:

First, perform a 50-g GLT (nonfasting), then check plasma glucose at 1 hour, at 24-28 weeks of gestation in women not previously diagnosed with overt diabetes. If the plasma glucose level is $\geq 130 \mathrm{mg} / \mathrm{dL}(7.2 \mathrm{mmol} / \mathrm{L})$, proceed to step 2 .

Second, the 100-g OGTT should be performed when the patient is fasting. If minimum two of the subsequent four criterias are met or exceeded, the diagnosis of GDM can be made: Fasting $95 \mathrm{mg} / \mathrm{dL}$ (5.3 mmol/L), $1 \mathrm{~h} 180 \mathrm{mg} / \mathrm{dL}$ (10 mmol/L), 2 h $155 \mathrm{mg} / \mathrm{dL}$ (8.6 mmol/L), 3 h $140 \mathrm{mg} / \mathrm{dL}$ (7.8 $\mathrm{mmol} / \mathrm{L})$ (ADA, 2018).

The patient test results was $144 \mathrm{mg} / \mathrm{dl}$ for 1 -hour 50-gram glucose load test with fasting blood glucose results of 99 mg/dl, 1 hour $224 \mathrm{mg} / \mathrm{dl}, 2$ hours $183 \mathrm{mg} / \mathrm{dl}$ and 3 hours 116 $\mathrm{mg} / \mathrm{dl}$ for 100 gram OGTT. So we diagnosed with GDM. 
GDM is commonly the result of cell dysfunction on a background of chronic insulin resistance during pregnancy. In most cases, these impairments exist before pregnancy and can be progressive representing an increased risk of T2DM post-pregnancy. Insulin resistance occurs because an increase in pregnancy hormones (human placental lactogen, progesterone, cortisol and prolactin) which peak at the third trimester of pregnancy (Barbour et al., 2007; Adam et al., 2014; Plows et al., 2018).

One of the causes of glucose impairment before pregnancy is iron overload. Iron overload can be caused by intensive transfusion. Transfusion is a treatment for beta thalassemias. Intensive transfusion treatment for beta thalassemias patients can provoke iron overload, increasing oxidative stress and promoting organ failure. The precise mechanism of ironinduced diabetes is uncertain. There are three hypotheses key mechanisms of iron induced diabetes i.e insulin deficiency, insulin resistance, and hepatic dysfunction. In a study of thalassemic patients, most patients were found to be insulin resistance (Swaminathan et al., 2007; Petrakos et al., 2016; Origa, 2018; Zhang et al., 2018).

The presence of insulin resistance can be determine by HOMA IR (normal value < 4). The function of pancreatic beta cells is measured by HOMA B (normal value of 70$150 \%$ ). We found the patient was in iron overload with ferritin 12696,12 mcg/l. There was also insulin resistance and $\beta$ cell dysfunction with fasting insulin $18.8 \mathrm{uIU} / \mathrm{ml}$, HOMA IR 4.6, HOMA $\beta$ 67\% (Wallace et al., 2004; Swaminathan et al., 2007; Adam et al., 2014).

After diagnosis, treatment starts with medical nutrition therapy, physical activity, and weight management and glucose monitoring aiming for the targets: Fasting < 95 $\mathrm{mg} / \mathrm{dL}$ (5.3 mmol/L), One-hour postprandial < $140 \mathrm{mg} / \mathrm{dL}$ $(7.8 \mathrm{mmol} / \mathrm{L})$ or two-hour postprandial $<120 \mathrm{mg} / \mathrm{dL}(6.7$ $\mathrm{mmol} / \mathrm{L})$. Studies show that $70-85 \%$ of women diagnosed with GDM can be treated with lifestyle modification alone. The food plan should be based on a nutrition assessment with guidance from the Dietary Reference Intakes (DRI). The DRI for all pregnant women recommends a minimum of $175 \mathrm{~g}$ of carbohydrate, $71 \mathrm{~g}$ of protein, and $28 \mathrm{~g}$ of fiber. Nutritional therapy at Dr. Soetome Hospital using diet B. For GDM, the diet $\mathrm{B} 1$ is given by calculating the number of calories as [Height (in cm) -100] x 30. For first trimester plus 100 calories, plus 200 calories for second trimester, 300 calories for third trimester and for breastfeeding mothers plus 400 calories. The composition of diet B1 is $60 \%$ carbohydrate, $20 \%$ protein and 20\% fat (Askandar et al., 2015; ADA, 2018).

Women with greater initial degrees of hyperglycemia or uncontrolled with lifestyle modification require pharmacologic therapy. Insulin is the first-line agent recommended for treatment of GDM.
The other pharmacology treatment for GDM are metformin and glyburide. Glyburide was associated with a higher rate of neonatal hypoglycemia and macrosomia. Metformin was associated with a lower risk of neonatal hypoglycemia and less maternal weight gain, however, metformin may slightly increase the risk of prematurity. We gave lifestyle modification with diet B1 T3 1800 calories, consisting of 270 gram of carbohydrate, 90 gram of protein, 40 gram of fat and 25-35 gram of fiber without glucose-lowering medication (ADA, 2018).

Women with a history of GDM have a greatly increased risk of conversion to type 2 diabetes. The OGTT is recommended at the time of the 4-12 week postpartum. If the result is normal, they should also be tested every 1-3 years thereafter with frequency of testing depending on other risk factors including family history, pre-pregnancy BMI, and need for glucose-lowering medication during pregnancy. Our patient returned two months after giving birth (8 weeks postpartum) with normal value of OGTT. Because our patient didn't breastfeed with a body weight $50 \mathrm{~kg}$ (BMI: $22.22 \mathrm{~kg} /$ $\mathrm{m} 2$ ), we gave her diet B1 1500 calories and oral chelating agent (ADA, 2018).

\section{CONCLUSION}

We have reported a case of pregnant woman 28 y.o with gestational diabetes mellitus and beta major thalassemia. GDM was controlled with lifestyle modification. The patient gave birth to a normal baby girl. GDM was caused by insulin resistance and beta cell dysfunction. Other risk factor in our patient was iron overload. The mechanism of iron-induced diabetes is likely to be mediated by insulin deficiency, insulin resistance, and hepatic dysfunction.

\section{REFERENCES}

Adam JM and Purnamasari D. 2014. Diabetes melitus gestasional. In: Setiati S, Alwi I, Sudoyo AW, Marcelius SK, Bambang S, Ari FS. Buku Ajar Ilmu Penyakit Dalam Ed IV. Jakarta, Interna Publishing, p2446-2431.

American Diabetes Association. 2018a. Management of diabetes in pregnancy: standards of medical care in diabetes2018. Diabetes Care 41(Supp1):S137-S143. doi: 10.2337/ dc18-S013.

American Diabetes Association. 2018b. Classification and diagnosis of diabetes: standards of medical care in diabetes2018. Diabetes Care 41(Supp1):13-27. doi: 10.2337/dc18S002.

Askandar T, Murtiwi S. 2015. Diet diabetes: terapi nutrisi medis. In: Tjokroprawiro A, Setiawan PB, Effendi C, Santoso D, Soegiarto G. Buku Ajar Ilmu Penyakit Dalam ed. 2. Surabaya, Airlanga University Press, p87-95. 
National Institute for Health and Care Excellence. 2015. Diabetes in pregnancy: management from preconception to the postnatal period. NICE guideline. Accessed 25 February 2015 .

Helin A, Kinnunen TI, Raitanen J, Ahonen S, Virtanen SM, Luoto R. 2012. Iron intake, haemoglobin and risk of gestational diabetes: a prospective cohort study. BMJ Open 2(5):1-8. doi: 10.1136/bmjopen-2012-001730.

Origa R. 2018. Beta-thalassemia. In: Adam MP, Ardinger HH, Pagon RA, et al. (Eds.). GeneReviews ${ }^{\circledR}$ [Internet]. Seattle (WA): University of Washington, Seattle; 1993-2020.

Petrakos G and Tsironi M. 2016. Pregnancy in women with thalassemia: challenges and solutions. International Journal of Women's Health 8:441-451.

Plows JF, Stanley JL, Baker PN, Reynolds CM, Vickers MH. 2018. The pathophysiology of gestational diabetes mellitus. Int J Mol Sci 19(11):3342. doi: 10.3390/ijms19113342.

Rani PR and Begum J. 2016. Screening and diagnosis of gestational diabetes mellitus, Where Do We Stand. Journal of Clinical and Diagnostic Research 10(4):QE01-QE04. doi: 10.7860/JCDR/2016/ 17588.7689.
Barbour LA, McCurdy CE, Hernandez TL, Kirwan JP, Catalano PR, Friedman JE. 2007. Cellular mechanisms for insulin resistance in normal pregnancy and gestational diabetes. Diabetes Care 30(Supp2):S112-S119. doi: $10.2337 / \mathrm{dc} 07-\mathrm{s} 202$.

Swaminathan S, Fonseca VA, Alam MG, Shah SV. 2007. The role of iron in diabetes and its complications. Diabetes Care 30(7):1926-1933. doi: 10.2337/dc06-2625.

Wallace TM, Levy JC, Matthews DR. 2004. Use and abuse of HOMA modeling. Diabetes Care 27(6):1487-1495. doi: 10.2337/diacare.27.6.1487.

World Health Organization. 2013. Diagnostic criteria and classification of hyperglycemia first detected in pregnancy. Available from https://www.ncbi.nlm.nih.gov/books/NBK 169024/.

Zhang X and Xiao Y. 2018. Investigating the reliability of HbA1c monitoring for blood glucose control during late pregnancy in patients with gestational diabetes mellitus (GDM) with and without $b$-thalassemia minor. Diabetes Therapy. Springer Healthcare 9(6):2305-2313. doi: 10.1007/s13300-018-0516-z. 